\title{
Fluctuations in environmental pollutants and air quality during the lockdown in the USA and China: two sides of COVID-19 pandemic
}

\author{
Awais Shakoor ${ }^{1} \cdot$ Xiaoyong Chen $^{3} \cdot$ Taimoor Hassan Farooq $^{2,3}$ (D) Umer Shahzad $^{6} \cdot$ Fatima Ashraf $^{4} \cdot$ Abdul Rehman $^{5}$. \\ Najam e Sahar ${ }^{7}$. Wende Yan $^{2,3}$
}

Received: 28 June 2020 / Accepted: 22 July 2020 / Published online: 9 August 2020

(C) Springer Nature B.V. 2020

\begin{abstract}
The World Health Organization declared the outbreak of the novel coronavirus (COVID-19) as a pandemic on March 11, 2020. Due to the global threat, many countries impose immediate lockdown. The impact of lockdown on the environmental pollutants and climate indicators gained considerable attention in the literature. This study aims to describe the variations in the environmental pollutants $\left(\mathrm{CO}, \mathrm{NO}_{2}, \mathrm{SO}_{2}, \mathrm{PM}_{2.5}\right.$ and $\left.\mathrm{PM}_{10}\right)$ with and without the lockdown period in the majorly hit states and provinces of the USA and China, respectively. Data during the first quarter year of 2019 and 2020 (lockdown period) was used in this study. Moreover, the effect of these pollutants on the pandemic spread was also studied. The results illustrated that the overall concentrations of $\mathrm{CO}_{2} \mathrm{NO}_{2}$ and $\mathrm{PM}_{2.5}$ were decreased by $19.28 \%, 36.7 \%$ and $1.10 \%$, respectively, while $\mathrm{PM}_{10}$ and $\mathrm{SO}_{2}$ were increased by $27.81 \%$ and $3.81 \%$ respectively in five selected states of the USA during the lockdown period. However, in the case of chosen provinces of China, overall, the concentrations of all selected pollutants, i.e., $\mathrm{CO}, \mathrm{NO}_{2}, \mathrm{SO}_{2}, \mathrm{PM}_{2.5}$ and $\mathrm{PM}_{10}$, were reduced by $26.53 \%, 38.98 \%, 18.36 \%, 17.78 \%$ and $37.85 \%$, respectively. The COVID-19 reported cases and deaths were significantly correlated with $\mathrm{NO}_{2}, \mathrm{PM}_{2.5}$ and $\mathrm{PM}_{10}$ in both China and the USA. The findings of this study concluded that the limited anthropogenic activities in the lockdown situation due to this novel pandemic disease result in a significant improvement of air quality by reducing the concentrations of environmental pollutants. As the trend goes on, the reduction of most pollutant concentrations is expected as long as partial or complete lockdown goes on. Keywords Coronavirus $\cdot$ Environmental gradients $\cdot \mathrm{USA} \cdot \mathrm{China} \cdot \mathrm{PM}_{2.5} \cdot \mathrm{PM}_{10}$
\end{abstract}

Electronic supplementary material The online version of this article (https://doi.org/10.1007/s11869-020-00888-6) contains supplementary material, which is available to authorized users.

Taimoor Hassan Farooq

taimoorhassan2055@gmail.com

$\triangle$ Wende Yan

csfuywd@hotmail.com

1 Department of Environment and Soil Sciences, University of Lleida, Avinguda Alcalde Rovira Roure 191, 25198 Lleida, Spain

2 College of Life Science and Technology, Central South University of Forestry and Technology, Changsha 410004, Hunan Province, People's Republic of China

3 National Engineering Laboratory for Applied Technology of Forestry and Ecology in South China, Changsha 410004, Hunan Province, People's Republic of China
4 Department of Chemistry, Lahore College for Women University, Lahore, Pakistan

5 CAS-Key Laboratory of Crust-Mantle Materials and the Environments, School of Earth and Space Sciences, University of Science and Technology of China, Hefei 230026, People's Republic of China

6 School of Statistics and Applied Mathematics, Anhui University of Finance and Economics, Bengbu 233030, People's Republic of China

7 School of Biological Sciences, Faculty of Environmental and Life Sciences, University of Southampton, Southampton, UK 


\section{Introduction}

COVID-19 infected cases were first reported in the last December in Wuhan, China (Gautam 2020; Huang et al. 2020; Tomar and Gupta 2020). It was a third outbreak of coronavirus after the severe acute respiratory syndrome (SARS) and the Middle East respiratory syndrome (MERS). A public health emergency was declared by the World Health Organization (WHO) on January 30, 2020 keeping in view the international concern. (Bashir et al. 2020a; WHO 2020). Initially, different case studies reported that COVID-19 had shallow fatality rate (2.3\%) (Shi et al. 2020; She et al. 2020) as compared to MERS (34.4\%) and SARS (9.2\%) (Wu et al. 2020; Ceccarelli et al. 2020). Nevertheless, a research study found that the number of COVID-19 patients doubled every 6.4 days, identifying that COVID-19 was a much more dangerous and infectious disease than expected (Wu et al. 2020).

The COVID-19 was reported to have reached the USA in early January 2020. In the USA, the first confirmed COVID-19 case of local transmission was found on January 15, 2020, in Washington state (Bashir et al. 2020b; Ghinai et al. 2020), and COVID-19 spread quickly throughout the country. California, Florida, Louisiana, North Carolina and Alabama states were the some of most infected states with the maximum number of cases and deaths in the USA. As of July 15, 2020, the total number of cases and deaths in California, Florida, Louisiana, North Carolina and Alabama states were 329,162 (7086), 282,435 (7277), 79,827 (3315), 87,528 (1510) and 55,545 (1124), respectively. On the other hand, the current situation in China may be different as the number of new cases and the death toll dropped significantly due to lockdown measurements (Bao and Zhang 2020). China has reported zero new cases for the first time since January on April 15, 2020.

Human health was significantly affected by air pollution. Globally, according to the State of Global Air Report 2019, air pollution approximately killed 5 million people in 2017, and the USA and China ranked among the top 10 countries with the maximum mortality rate (Health Effects Institute (HEI), https://www.healtheffects.org/). In addition to human-tohuman transmission, environmental parameters play an important role in terms of transmission, distribution viability, the timing of infections and range of viruses spread (Anser et al. 2020; Lemaitre et al. 2019; Șahin 2020; Shi et al. 2020; van Doremalen et al. 2013; Zhu et al. 2020).

The majority of the world population faced lockdown during these hard times. By this nationwide COVID-19 lockdown, transport, as well as industrial activities, significantly reduced. Besides the possible side effects of this unprecedented lockdown, environmental pollution drastically decreased in many countries. In India, as a result of lockdown, the air pollution in 88 cities across the country dramatically reduced down only after four days of commencing lockdown (Mahato et al. 2020; Sharma et al. 2020). European Space Agency
(ESA) and National Aeronautics and Space Administration (NASA) pollution monitoring satellites have identified significant reductions in $\mathrm{NO}_{2}$ emissions over Italy during the lockdown period (ESA 2020; Muhammad et al. 2020; NASA 2020). Similarly, the IESM (Institute of Environmental Science and Meteorology) reported that the emissions of $\mathrm{PM}_{10}$ and $\mathrm{PM}_{2.5}$ were reduced due to decreased industrial activities as a result of lockdown measurements. Additionally, Finland's center for research on energy and clean air studied and accounted that almost $25 \%$ of $\mathrm{CO}_{2}$ emissions reduced due to factory closures and travel restrictions in China (Carbon Brief 2020).

Since COVID-19 is an acute respiratory disease and could remain feasible in aerosols for hours (van Doremalen et al. 2020), the main objectives of this study are to investigate the effect of reduced human activities and lockdown on environmental indicators and changes in air quality in the USA and China, and to examine the correlation between COVID-19 spread and the environmental pollutants in those respective states and provinces. Data about the various air pollutants such as $\mathrm{CO}, \mathrm{NO}_{2}, \mathrm{SO}_{2}, \mathrm{PM}_{2.5}$ and $\mathrm{PM}_{10}$ was used (Abdul-Wahab et al. 2020).

\section{Methods}

According to our objectives, California, Florida, Louisiana, North Carolina, and Alabama were selected from the USA. While Hubei, Beijing, Shanghai, Guangdong, and Zhejiang were chosen from China, these provinces were considered as the industrial hubs in China and they were also among the worst hit by COVID-19 (Kucharski et al. 2020; Leung et al. 2020).

To perform the comparison study between pollutants in the first quarter of 2019 and 2020, data was collected between January 1 and April 30 of 2019 and 2020 from an online platform of the Environmental Protection Agency (EPA) (https://www.epa.gov/) and the MEE (http://datacenter.mee. gov.cn/) websites for the USA and China, respectively. In this study, daily 24-h concentrations of pollutants such as carbon monoxide $(\mathrm{CO})$, nitrogen dioxide $\left(\mathrm{NO}_{2}\right)$, sulfur dioxide $\left(\mathrm{SO}_{2}\right), \mathrm{PM}_{2.5}$ and $\mathrm{PM}_{10}$ were measured. For the USA, concentrations were taken between March 19, 2019 to April 30, 2019, and March 19, 2020 to April 30, 2020 (this was the lockdown time in the USA). While for China, environmental indicators concentrations were taken between Jan 23, 2019 to March 29, 2019, and Jan 23, 2020 to March 29, 2020 (this was the lockdown time in China).

The data of confirmed COVID-19 cases and deaths of the USA were retrieved from the official website of the Centers for Disease Control (CDC) (https://www.cdc.gov/). While for China, data on COVID-19, including the number of confirmed cases and deaths, were extracted from the China National Health Commission website (CNHC, http://www. 
nhc.gov.cn/). To find the association between COVID-19 and environmental pollutants, COVID-19 data between January 18, 2020 to March 25, 2020, for China and March 1, 2020 to April 30, 2020, for the USA was used. As the data was not normally distributed, therefore, Spearman and Kendall rank correlation tests were used to determine the correlation between variables.

\section{Results and discussion}

\section{Changes in air quality and environmental pollutants}

Data in Table 1 shows the reduction percentage of daily concentration of environmental pollutants in the first

Table 1 Percentage of reduction of the environmental pollutants (average concentration) in the first quarter of 2019 and 2020 among the significantly hit states of the USA and China ( $N A=$ not available)

\begin{tabular}{|c|c|c|}
\hline Pollutant & Reduction \% & Reduction \% \\
\hline & California & Hubei \\
\hline $\mathrm{CO}(\mathrm{ppm})$ & NA & 11.02 \\
\hline $\mathrm{NO}_{2}(\mathrm{ppb})$ & 44.22 & 49.21 \\
\hline $\mathrm{SO}_{2}(\mathrm{ppb})$ & 88.7 & 9.33 \\
\hline $\mathrm{PM}_{2.5}\left(\mathrm{ug} / \mathrm{m}^{3}\right)$ & 27.67 & 16.20 \\
\hline \multirow[t]{2}{*}{$\mathrm{PM}_{10}\left(\mathrm{ug} / \mathrm{m}^{3}\right)$} & 19.86 & 31.0 \\
\hline & Florida & Beijing \\
\hline $\mathrm{CO}(\mathrm{ppm})$ & 4.70 & 11.02 \\
\hline $\mathrm{NO}_{2}(\mathrm{ppb})$ & 35.41 & 25.64 \\
\hline $\mathrm{SO}_{2}(\mathrm{ppb})$ & 73.33 & 42.64 \\
\hline $\mathrm{PM}_{2.5}\left(\mathrm{ug} / \mathrm{m}^{3}\right)$ & 33.72 & 6.48 \\
\hline \multirow[t]{2}{*}{$\mathrm{PM}_{10}\left(\mathrm{ug} / \mathrm{m}^{3}\right)$} & 32.29 & 79.07 \\
\hline & Louisiana & Shanghai \\
\hline $\mathrm{CO}(\mathrm{ppm})$ & 33.33 & 18.21 \\
\hline $\mathrm{NO}_{2}(\mathrm{ppb})$ & 61.16 & 43.78 \\
\hline $\mathrm{SO}_{2}(\mathrm{ppb})$ & 82.26 & 31.19 \\
\hline $\mathrm{PM}_{2.5}\left(\mathrm{ug} / \mathrm{m}^{3}\right)$ & 10.83 & 26.60 \\
\hline \multirow[t]{2}{*}{$\mathrm{PM}_{10}\left(\mathrm{ug} / \mathrm{m}^{3}\right)$} & -61.64 & 29.14 \\
\hline & North Carolina & Guangdong \\
\hline $\mathrm{CO}(\mathrm{ppm})$ & 12.59 & 25.69 \\
\hline $\mathrm{NO}_{2}(\mathrm{ppb})$ & 29.24 & 32.38 \\
\hline $\mathrm{SO}_{2}(\mathrm{ppb})$ & -39.89 & -10.32 \\
\hline $\mathrm{PM}_{2.5}\left(\mathrm{ug} / \mathrm{m}^{3}\right)$ & 29.21 & 19.82 \\
\hline \multirow[t]{2}{*}{$\mathrm{PM}_{10}\left(\mathrm{ug} / \mathrm{m}^{3}\right)$} & 35.17 & 26.41 \\
\hline & Alabama & Zhejiang \\
\hline $\mathrm{CO}(\mathrm{ppm})$ & NA & 66.83 \\
\hline $\mathrm{NO}_{2}(\mathrm{ppb})$ & NA & 43.89 \\
\hline $\mathrm{SO}_{2}(\mathrm{ppb})$ & 88.70 & 18.96 \\
\hline $\mathrm{PM}_{2.5}\left(\mathrm{ug} / \mathrm{m}^{3}\right)$ & 30.71 & 19.78 \\
\hline $\mathrm{PM}_{10}\left(\mathrm{ug} / \mathrm{m}^{3}\right)$ & NA & 23.62 \\
\hline
\end{tabular}

quarter of 2019 and 2020 in the five states/provinces of the USA and China.

Figure 1 shows the concentrations with and without lockdown in the studied states of the USA. In California, the concentrations of all five pollutants significantly decreased during the lockdown period than the previous year. The maximum reduction $(23.1 \%)$ in the concentration was observed in $\mathrm{NO}_{2}$. Moreover, $19.6 \%$ and $17.7 \%$ reductions were detected in $\mathrm{PM}_{10}$ and $\mathrm{PM}_{2.5}$, respectively. In Florida, a higher reduction was observed in $\mathrm{NO}_{2}$ concentration $(21.1 \%)$, and almost similar reductions were reported in both $\mathrm{CO}$ and $\mathrm{SO}_{2}$ concentrations. Moreover, in the $\mathrm{PM}_{2.5}$ and $\mathrm{PM}_{10}$ concentration, $32.29 \%$ and $33.72 \%$ reduction was observed. In Louisiana, the concentrations of $\mathrm{CO}, \mathrm{NO}_{2}, \mathrm{SO}_{2}$ and $\mathrm{PM}_{2.5}$ were decreased with $36.3 \%$. 59.8\%, $8.28 \%$ and $22.2 \%$, respectively. While $\mathrm{PM}_{10}$ had a $24.5 \%$ increase as compared with the previous year. The increase in the concentration of $\mathrm{PM}_{10}$ might be due to anthropogenic sources (Klimont et al. 2017). In North Carolina, significant reductions were seen in all environmental pollutants except for $\mathrm{SO}_{2}$. The maximum reduction was observed in $\mathrm{PM}_{2.5}$ (30.8\%) than other pollutants. On the other hand, $\mathrm{PM}_{2.5}$ significantly increased up to $23.8 \%$ in Alabama state.

As we all know, China was the first country that reported COVID-19 patients in the Wuhan seafood market (Nishiura et al. 2020). As of January 19, 2020, the Chinese authorities declared a public health emergency, and then Wuhan underwent a complete lockdown. Environmental pollutants were significantly affected by lockdown measurements. Overall, an apparent reduction can be seen in the first quarter of 2020 as compared with 2019. Figure 2 represents the comparisons of the average concentrations of environmental pollutants in the first quarter of 2019 and 2020 among the different provinces of China.

In China, in all five provinces, the environmental pollutants significantly decreased during the lockdown period as compared to a similar period of 2020. In Hubei, the reduction concentrations were $11.02 \%, 49.21 \%, 9.33 \%, 16.20 \%$ and $31 \%$ for $\mathrm{CO}, \mathrm{NO}_{2}, \mathrm{SO}_{2}, \mathrm{PM}_{2.5}$ and $\mathrm{PM}_{10}$ respectively (Fig. 2). Beijing is the capital of China, with 21.54 million populations and air pollution significantly affected the community in this city. During this pandemic period, air pollution significantly decreased as compared with the previous year. The concentrations of $\mathrm{PM}_{2.5}$ in Beijing, Shanghai, Guangdong and Zhejiang decreased by $6.48 \%, 26.6 \%, 19.82 \%$ and $19.78 \%$, respectively, while $\mathrm{PM}_{10}$ decreased by $79.07 \%$, $29.14 \%, 26.41 \%$ and $23.62 \%$, respectively. In Shanghai, the reductions in the concentrations of $\mathrm{CO}, \mathrm{NO}_{2}$ and $\mathrm{SO}_{2}$ were $18.21 \%, 43.73 \%$ and $31.19 \%$, respectively. Similar conclusions can be derived from Guangdong and Zhejiang provinces.

Globally, air pollution dramatically decreased due to unprecedented lockdown (Bao and Zhang 2020). According to 
Fig. 1 Changes in the concentrations of environmental pollutants with and without lockdown condition in the five figures, data about a few states is the data of particular pollutants in those states (Lous is Louisiana; NCarolina is North Carolina and Albm is Alabama) states of the USA. In some submissing; we were not able to find
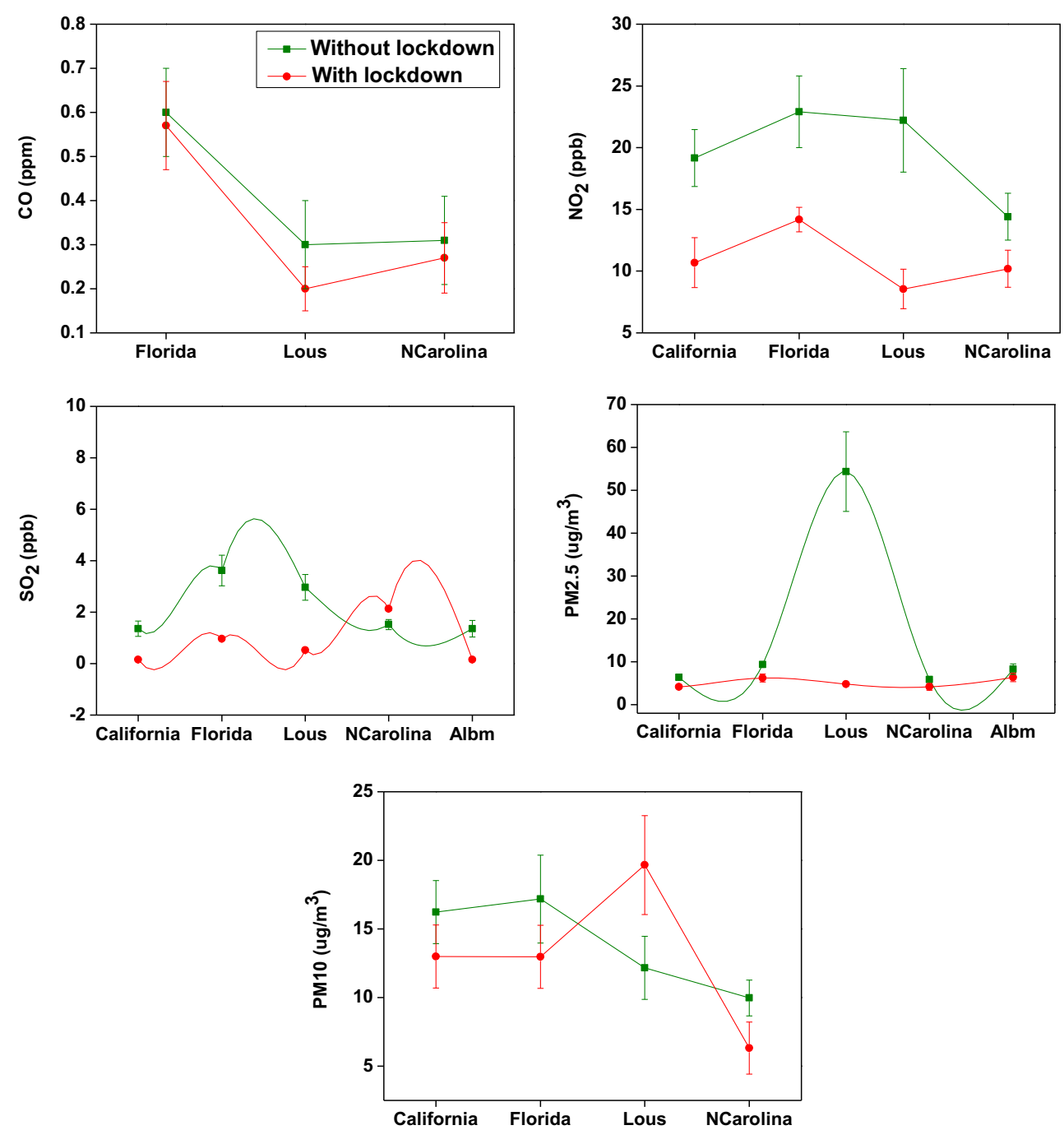

our results, significant concentrations of pollutants were reduced in the first quarter year of 2020 as compared with 2019 (Figs. 1 and 2). Our results were similar to recent research studies (Bao and Zhang 2020; Sharma et al. 2020). In Italy, $\mathrm{NO}_{2}$ concentrations were decreased during the lockdown period (Reuters 2020). According to Sharma et al. (2020), concentrations of $\mathrm{PM}_{10}, \mathrm{PM}_{2.5}$ and $\mathrm{NO}_{2}$ were reduced in north India, clearly showing the positive effect of lockdown on air quality measurements. During the COVID-19 pandemic, almost every country closed its industrial as well as commercial activities to stop the spread of the COVID-19. This might be the main reason for the reduction of environmental pollutants. Wang et al. (2020) found that the concentration of environmental pollutants, especially $\mathrm{PM}_{2.5}$, significantly decreased due to the suspension of industry and transportation in China.

Correlation coefficient analysis was used to reveal the interaction between pollutants (first quarter of 2020) of states and provinces of the USA and China, respectively (Fig. 3). In the USA, all five environmental pollutants showed strong associations with states except $\mathrm{SO}_{2}$ (Fig. 3a). However, in
China, $\mathrm{CO}, \mathrm{SO}_{2}, \mathrm{PM}_{2.5}$ and PM10 had shown a positive correlation with each other, but a negative correlation was observed in $\mathrm{NO}_{2}$ (Fig. 3b).

\section{Association between COVID-19 and environmental pollutants}

In the USA, the number of confirmed COVID-19 cases and deaths increases rapidly than China. As of June 15, 2020, a total of 3,296,599 confirmed cases with 134,884 deaths had been reported by the Centers for Disease Control (CDC) (https://www.cdc.gov/) in the USA. It might be possible that environmental pollutants play an important role in the transmission of COVID-19 disease. Table 2 shows the empirical results of the association between COVID-19 (cases and states and provinces of the USA and China, respectively.

Statistical significance at the $* P<0.05 ; * * P<0.01$; $* * * P<0.001$ deaths) and environmental pollutants across all the study 
Fig. 2 Changes in the concentrations of environmental pollutants with and without lockdown condition in the five provinces of China (Gdong is Guangdong)
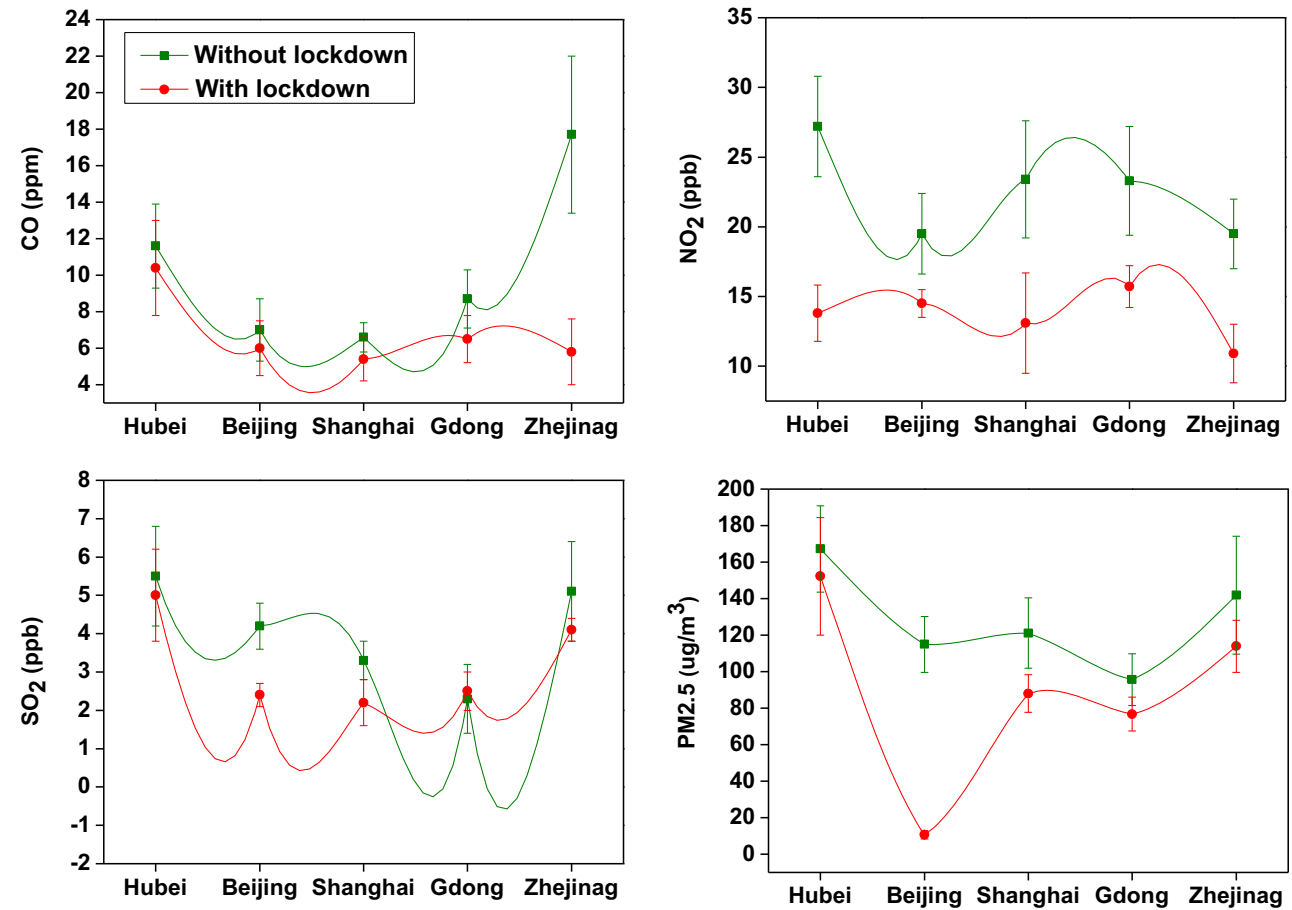

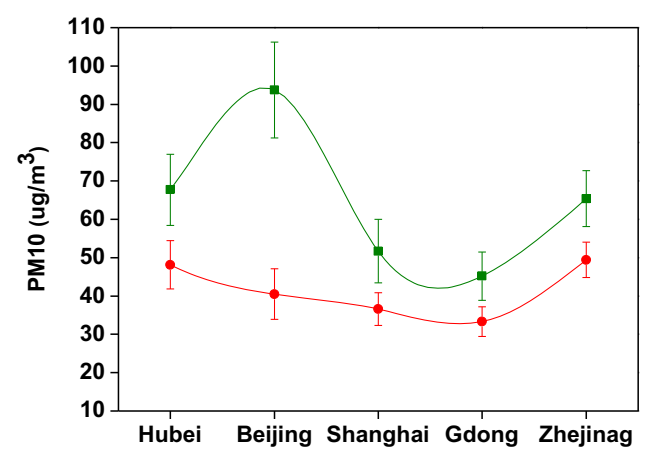

Our findings show that COVID-19 cases and deaths are significantly correlated with environmental pollutants in both the USA and China. In the USA, we observed significant positive associations of $\mathrm{NO}_{2}, \mathrm{PM}_{2.5}$ and $\mathrm{PM}_{10}$ with COVID-
19 confirmed cases and deaths in Spearman correlation. While in the Kendall correlation coefficient, we found that $\mathrm{PM}_{2.5}$ and $\mathrm{PM}_{10}$ had a significant correlation with COVID-19 cases and mortality. Moreover, $\mathrm{PM}_{10}$ showed a strong association with
Fig. 3 Correlation between environmental pollutants in (a) the USA and (b) China in the first quarter of 2020

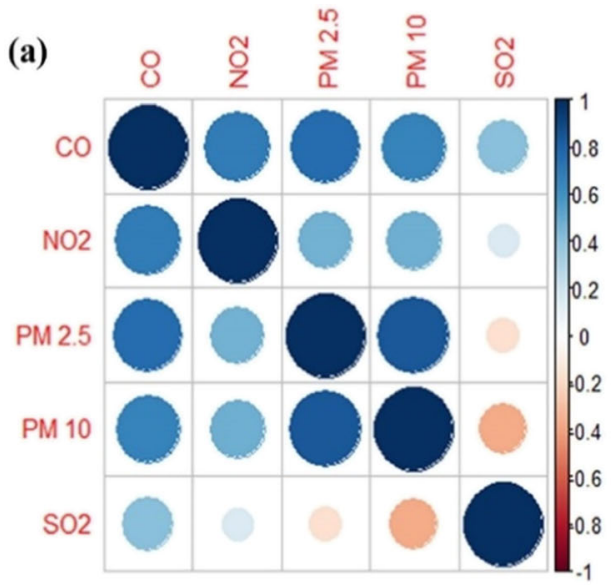


Table 2 The correlation coefficient between COVID-19, confirmed cases and deaths across all the study states and provinces of the USA and China, respectively

\begin{tabular}{|c|c|c|c|c|}
\hline \multirow[b]{2}{*}{ Pollutants } & \multicolumn{2}{|l|}{ USA } & \multicolumn{2}{|l|}{ China } \\
\hline & Cases & Mortality & Cases & Mortality \\
\hline \multicolumn{5}{|c|}{ Spearman correlation coefficient } \\
\hline $\mathrm{CO}$ & -0.024 & -0.044 & 0.186 & -0.053 \\
\hline $\mathrm{NO}_{2}$ & $-0.067 *$ & $-0.139 * *$ & $-0.516 * * *$ & $-0.397 * * *$ \\
\hline $\mathrm{SO}_{2}$ & 0.018 & 0.115 & -0.161 & -0.088 \\
\hline $\mathrm{PM}_{2.5}$ & $-0.392 *$ & $-0.263 *$ & $-0.081 * *$ & $-0.166^{*}$ \\
\hline $\mathrm{PM}_{10}$ & $0.086^{*}$ & $0.356 * * *$ & $-0.529 * * *$ & $-0.507 * * *$ \\
\hline \multicolumn{5}{|c|}{ Kendall correlation coefficient } \\
\hline $\mathrm{CO}$ & -0.015 & -0.024 & 0.153 & -0.034 \\
\hline $\mathrm{NO}_{2}$ & -0.042 & -0.095 & $-0.353 * * *$ & $-0.273 * * *$ \\
\hline $\mathrm{SO}_{2}$ & 0.013 & 0.077 & -0.112 & -0.533 \\
\hline $\mathrm{PM}_{2.5}$ & $-0.279 *$ & $-0.184 *$ & $-0.049 * *$ & $-0.112 *$ \\
\hline $\mathrm{PM}_{10}$ & $0.053 *$ & $0.233 * * *$ & $-0.362 * * *$ & $-0.360 * * *$ \\
\hline
\end{tabular}

mortality rates in both Spearman and Kendall correlations. In China, statistical analysis showed that $\mathrm{NO}_{2}, \mathrm{PM}_{2.5}$ and $\mathrm{PM}_{10}$ had a significantly positive correlation with COVID-19 cases and deaths in both Spearman and Kendall correlations (Table 2).

After continuous scientific research, clear shreds of evidence are showed that human health was significantly affected by air pollution, particularly in urban areas. Bashir et al. (2020a) studied and analyzed that $\mathrm{CO}, \mathrm{PM}_{2.5}, \mathrm{PM}_{10}$ and $\mathrm{SO}_{2}$ were positively associated with COVID-19 cases and deaths in the California state. Xiao et al. (2020) also found a strong correlation between environmental pollutants and COVID-19. He also proposed that only $1 \mathrm{\mu g} \mathrm{m}^{-3}$ increase in the concentration of $\mathrm{PM}_{2.5}$ can increase up to $15 \%$ in the fatality rate. A study from Thailand showed that $\mathrm{CO}, \mathrm{PM}_{10}$, $\mathrm{NO}_{2}, \mathrm{O}_{3}$ and $\mathrm{SO}_{2}$ significantly increased the risk of respiratory diseases (Phosri et al. 2019). Yao et al. (2020) also analyzed the spatial correlation of $\mathrm{PM}_{2.5}$ and $\mathrm{PM}_{10}$ and the COVID-19 casualty rate by using multiple regression methods in China and found that $\mathrm{PM}_{2.5}$ and $\mathrm{PM}_{10}$ with higher concentration had a positive association with COVID-19 deaths. Zhao et al. (2019) studied and showed that highly pathogenic avian influenza (HPAI) virus was carried by fine particulate matter $\left(\mathrm{PM}_{2.5}\right)$ in Iowa state, from infected places both within a state and neighboring states. On March 16, 2020, Setti et al. (2020a) published a study and found that an airborne route was a possible additional factor for interpreting the anomalous COVID-19 outbreaks notified in Northern Italy, known to be one of the European areas characterized by highest PM concentration. Another research study showed that a higher concentration of $\mathrm{PM}_{10}\left(>50 \mu \mathrm{g} \mathrm{m}^{-3}\right)$ results in a spread acceleration of COVID-19, suggesting a "boost effect" for the viral infection (Setti et al. 2020b). Additionally, the other researchers showed that pollution caused by $\mathrm{PM}_{10}$ affects the prognosis of COVID-19 patients (Bashir et al. 2020a). On the other hand, Bernardini et al. (2020) studied the association between environmental pollutants $\left(\mathrm{CO}, \mathrm{NO}_{2}, \mathrm{O}_{3}\right.$, and $\left.\mathrm{PM}\right)$ and COVID-19 in Italy and found a significant positive correlation between them. Likewise, other researchers such as Adach et al. (2020), Ha (2020), and Zhu et al. (2020) also observed similar findings. This evidence supports our study and suggests that COVID-19 might spread through environmental pollutants.

This study may have some limitations. Firstly, we studied the association between COVID-19 infection and environmental pollutants, but our findings were not globally representative as we only included five states and five provinces of the USA and China, respectively. Secondly, in this study, we could not examine the impact of all elements of lockdown measurements (smart lockdown or complete lockdown) due to the lack of data availability. Thirdly, this study did also not include age or gender-specific COVID-19 confirmed cases and deaths; therefore, we could not perform subgroup analyses. Future studies should address these limitations.

\section{Conclusions}

The study includes the comparison release of environmental pollutants $\left(\mathrm{CO}, \mathrm{NO}_{2}, \mathrm{SO}_{2}, \mathrm{PM}_{2.5}\right.$ and $\left.\mathrm{PM}_{10}\right)$ in the first quarter of 2019 and 2020 with a lockdown period of five states of the USA and five provinces of China. The results suggest that restricted human activities during the lockdown period have significantly reduced the concentrations of environmental pollutants in both countries. Among selected pollutants, $\mathrm{NO}_{2}$, $\mathrm{PM}_{2.5}$ and $\mathrm{PM}_{10}$ were observed significantly correlated with COVID-19 disease. The study helps to understand the implication of restricted anthropogenic activities in the reduction of environmental pollutants and to speculate the execution of some meticulous measures to improve the air quality.

\section{Compliance with ethical standards}

Conflict of interest The authors declare that they have no conflict of interest.

\section{References}

Abdul-Wahab SA, Fadlallah SO, Al-Riyami M et al (2020) A study of the effects of $\mathrm{CO}, \mathrm{NO} 2$, and PM10 emissions from the Oman Liquefied Natural Gas (LNG) plant on ambient air quality. Air Qual Atmos Health. https://doi.org/10.1007/s11869-020-00876-w

Adach W, Błaszczyk M, Olas B (2020) Carbon monoxide and its donors chemical and biological properties. Chem Biol Interact 318:108973. https://doi.org/10.1016/j.cbi.2020.108973 
Anser MK, Yousaf Z, Khan MA, Voo XH, Nassani AA, Alotaibi SM, Abro MMQ, Zaman K (2020) The impacts of COVID-19 measures on global environment and fertility rate: double coincidence. Air Qual Atmos Health. https://doi.org/10.1007/s11869-020-00865-Z

Bao R, Zhang A (2020) Does lockdown reduce air pollution? Evidence from 44 cities in northern China. Sci Total Environ 731:139052. https://doi.org/10.1016/j.scitotenv.2020.139052

Bashir MF, Ma BJ, Bilal KB, Bashir MA, Farooq TH et al (2020a) Correlation between environmental pollution indicators and COVID-19 pandemic: a brief study in Californian context. Environ Res 187:109652. https://doi.org/10.1016/j.envres.2020. 109652

Bashir MF, Ma B, Komal B, Bashir MA, Tan D, Bashir M (2020b) Correlation between climate indicators and COVID-19 pandemic in New York, USA. Sci Total Environ 728:138835. https://doi.org/ 10.1016/j.scitotenv.2020.138835

Bernardini F, Attademo L, Trezzi R, Gobbicchi C, Balducci PM, Del Bello V et al (2020) Air pollutants and a daily number of admissions to psychiatric emergency services: evidence for detrimental mental health effects of ozone. Epidemiol Psychiatr Sci 29:66. https://doi. org/10.1017/S2045796019000623

Carbon Brief (2020) Finland's center for research on energy and clean air. https://www.carbonbrief.org.

Ceccarelli M, Berretta M, Venanzi RE (2020) Differences and similarities between severe acute respiratory syndrome (SARS)-coronavirus $(\mathrm{CoV})$ and SARS-CoV-2. Would a rose by another name smell as sweet? Eur Rev Med Pharmacol Sci 24:2781-2783. https://doi.org/ $10.26355 /$ eurrev

ESA (2020) European Space Agency. https://www.esa.int/

Gautam S (2020) COVID-19: air pollution remains low as people stay at home. Air Qual Atmos Health:1

Ghinai I, McPherson TD, Hunter JC, Kirking HL, Christiansen D, Joshi $\mathrm{K}$, Rubin $\mathrm{R}$ et al (2020) First known person-to-person transmission of severe acute respiratory syndrome coronavirus 2 (SARS-CoV-2) in the USA. Lancet 395:1137-1144. https://doi.org/10.1016/S01406736(20)30607-3

Ha E (2020) Impact of air pollution hazards on human development BTHealth Impacts of Developmental Exposure to Environmental Chemicals 223-245. https://doi.org/10.1007/978-981-15-0520-1 10

Huang C, Wang Y, Li X, Ren L, Zhao J, Hu Y, Zhang L, Fan G, Xu J, Gu X, Cheng Z, Yu T, Xia J, Wei Y, Wu W, Xie X, Yin W, Li H, Liu M, Xiao Y, Gao H, Guo L, Xie J, Wang G, Jiang R, Gao Z, Jin Q, Wang J, Cao B (2020) Clinical features of patients infected with 2019 novel coronavirus in Wuhan, China. Lancet 395:497-506. https://doi.org/10.1016/S0140-6736(20)30183-5

Klimont Z, Kupiainen K, Heyes C, Purohit P, Cofala J, Rafaj P, BorkenKleefeld J, Schöpp W (2017) Global anthropogenic emissions of particulate matter including black carbon. Atmos Chem Phys 17: 8681-8723. https://doi.org/10.5194/acp-17-8681-2017

Kucharski AJ, Russell TW, Diamond C, Liu Y, Edmunds J, Funk S, Eggo RM, Sun F, Jit M, Munday JD, Davies N, Gimma A, van Zandvoort K, Gibbs H, Hellewell J, Jarvis CI, Clifford S, Quilty BJ, Bosse NI, Abbott S, Klepac P, Flasche S (2020) Early dynamics of transmission and control of COVID-19: a mathematical modeling study. Lancet Infect Dis 20:553-558. https://doi.org/10.1016/S14733099(20)30144-4

Lemaitre J, Pasetto D, Perez-Saez J, Sciarra C, Wamala JF, Rinaldo A (2019) Rainfall as a driver of epidemic cholera: comparative model assessments of the effect of intra-seasonal precipitation events. Acta Trop 190:235-243. https://doi.org/10.1016/j.actatropica.2018.11. 013

Leung K, Wu JT, Liu D, Leung GM (2020) First-wave COVID-19 transmissibility and severity in China outside Hubei after control measures, and second-wave scenario planning: a modeling impact assessment. Lancet 395:1382-1393. https://doi.org/10.1016/S01406736(20)30746-7
Mahato S, Pal S, Ghosh KG (2020) Effect of lockdown amid COVID-19 pandemic on air quality of the megacity Delhi, India. Sci Total Environ 730:139086. https://doi.org/10.1016/j.scitotenv.2020. 139086

Muhammad S, Long X, Salman M (2020) COVID-19 pandemic and environmental pollution: a blessing in disguise? Sci Total Environ 728:138820. https://doi.org/10.1016/j.scitotenv.2020.138820

NASA (2020) National Aeronautics and Space Administration. https:// www.nasa.gov/

Nishiura H, Jung S, Linton NM, Kinoshita R, Yang Y, Hayashi K, Kobayashi T, Yuan B, Akhmetzhanov AR (2020) The extent of transmission of novel coronavirus in Wuhan, China, 2020. J Clin Med 9:330. https://doi.org/10.3390/jcm9020330

Phosri A, Ueda K, Phung VLH, Tawatsupa B, Honda A, Takano H (2019) Effects of ambient air pollution on daily hospital admissions for respiratory and cardiovascular diseases in Bangkok, Thailand. Sci Total Environ 651:1144-1153. https://doi.org/10.1016/j. scitotenv.2018.09.183

Reuters (2020) Italy headlines. https://www.reuters.com/article/us-healthcoronavirus-italy-pollution/air-pollution-clears-in-northern-italy-aftercoronavirus-lockdown-satellite-shows idUSKBN2102X4

Şahin M (2020) Impact of weather on COVID-19 pandemic in Turkey. Sci Total Environ 728:138810. https://doi.org/10.1016/j.scitotenv. 2020.138810

Setti L, Passarini F, de Gennaro G, Di Gilio A, Palmisani J, Buono P et al (2020a) Evaluation of the potential relationship between particulate matter (PM) pollution and COVID-19 infection spread in Italy. SIMA Position Pap.

Setti L, Passarini F, de Gennaro G, Barbieri P, Perrone MG, Piazzalunga A et al (2020b) The potential role of particulate matter in the spreading of COVID-19 in Northern Italy: first evidence-based research hypotheses. medRxiv 2020.04.11.20061713. https://doi.org/10. $1101 / 2020.04 .11 .20061713$

Sharma S, Zhang M, Anshika GJ, Zhang H, Kota SH (2020) Effect of restricted emissions during COVID-19 on air quality in India. Sci Total Environ 728:138878. https://doi.org/10.1016/j.scitotenv.2020. 138878

She J, Jiang J, Ye L, Hu L, Bai C, Song Y (2020) 2019 novel coronavirus of pneumonia in Wuhan, China: emerging attack and management strategies. Clin Transl Med 9:19. https://doi.org/10.1186/s40169020-00271-Z

Shi P, Dong Y, Yan H, Zhao C, Li X, Liu W, He M, Tang S, Xi S (2020) Impact of temperature on the dynamics of the COVID-19 outbreak in China. Sci Total Environ 728:138890. https://doi.org/10.1016/j. scitotenv.2020.138890

Tomar A, Gupta N (2020) Prediction for the spread of COVID-19 in India and the effectiveness of preventive measures. Sci Total Environ 728: 138762. https://doi.org/10.1016/j.scitotenv.2020.138762

van Doremalen N, Bushmaker T, Munster VJ (2013) Stability of middle east respiratory syndrome coronavirus (MERS-CoV) under different environmental conditions. Eurosurveillance 18:1-4. https://doi.org/ 10.2807/1560-7917.ES2013.18.38.20590

van Doremalen N, Bushmaker T, Morris DH, Holbrook MG, Gamble A, Williamson BN et al (2020) Aerosol and surface stability of SARSCoV-2 as compared with SARS-CoV-1. N Engl J Med 0-3

Wang P, Chen K, Zhu S, Wang P, Zhang H (2020) Severe air pollution events not avoided by reduced anthropogenic activities during COVID-19 outbreak. Resour Conserv Recycl 158:104814. https:// doi.org/10.1016/j.resconrec.2020.104814

WHO (2020) World Health Organization-Coronavirus Disease 2019 (COVID-19) Situation Report - 97. https://doi.org/10.1213/xaa. 0000000000001218

Wu JT, Leung K, Leung GM (2020) Nowcasting and forecasting the potential domestic and international spread of the 2019-nCoV outbreak originating in Wuhan, China: a modeling study. Lancet 395: 689-697. https://doi.org/10.1016/S0140-6736(20)30260-9 
Xiao Wu, Rachel CN, Sabath MB, Braun D, Xiao FD (2020). Exposure to air pollution and COVID-19 mortality in the United States: a nationwide cross-sectional study, medRxiv. https://doi.org/10. 1017/CBO9781107415324.004

Yao Y, Pan J, Wang W, Liu Z, Kan H, Meng X, Wang W (2020) Spatial correlation of particulate matter pollution and death rate of COVID19/China/PM2.5, PM10/multiple linear regression. medRxiv.

Zhao Y, Richardson B, Takle E, Chai L, Schmitt D, Xin H (2019) Airborne transmission may have played a role in the spread of 2015 highly pathogenic avian influenza outbreaks in the United
States. Sci Rep 9:1-10. https://doi.org/10.1038/s41598-019-47788$\mathrm{Z}$

Zhu Y, Xie J, Huang F, Cao L (2020) Association between short-term exposure to air pollution and COVID-19 infection: evidence from China. Sci Total Environ 727:138704. https://doi.org/10.1016/j. scitotenv.2020.138704

Publisher's note Springer Nature remains neutral with regard to jurisdictional claims in published maps and institutional affiliations. 